\title{
PREDIKSI PENYAKIT LIVER DENGAN MENGGUNAKAN METODE DECISION TREE DAN NEURAL NETWORK
}

\author{
Popon Handayani ${ }^{1}$, Elah Nurlelah ${ }^{2}$, Mugi Raharjo ${ }^{3}$,Panji Madya Ramdani ${ }^{4}$ \\ ${ }^{123}$ STMIK Nusa Mandiri Jakarta \\ Jln. Damai No 8, Warung Jati, Marga Satwa,Pasar Minggu,Jakarta Selatan,Indonesia \\ ${ }^{4}$ Universitasi BSI \\ Jln. Kamal Raya No.18 Cengkareng,Jakarta Barat,Indonesia \\ 1'popon.pph@nusamandiri.ac.id, ${ }^{2}$ elah.enl@bsi.ac.id, ${ }^{3}$ mugi.mou@bsi.ac.id, ${ }^{4}$ panji.pmr@bsi.ac.id
}

\begin{abstract}
Abstrak - Penyakit Liver merupakan penyakit dimana disebabkan oleh berbagai faktor yang merusak hati, seperti virus,penggunaan alkohol dan lainnya. Dalam hal penanganan pasien pada tahap awal sangatlah penting untuk kelangsungan pasien dan penyakit hati tidak mudah ditemukan pada stadium awal. Untuk itu kami melakukan sebuah penelitian dengan menggunakan dua metode yaitu metode Decision Tree dan Metode Neural Network untuk mengetahui nilai akurasinya. Berdasarkan hasil perbandingan, diperoleh neural network terbaik dalam mendeteksi penyakit hati.
\end{abstract}

Keywords - Liver, Decision Tree, Neural Network..

\section{PENDAHULUAN}

Kesehatan merupakan salah satu hal terpenting dalam hidup manusia, Hal ini menjadi dasar bahwasanya banyak ditemukannya temuan-temuan ilmiah baik berupa temuan obat-obatan, alat kesehatan atau penemuan-penemuan baru di bidang kesehatan. Berbicara mengenai kesehatan tentunya berhubungan dengan penyakit, sejak dahulu banyak sekali penyakit-penyakit bermunculan entah itu datangnya dari virus,bakteri, parasite, sel kanker dan lain-lain. Salah satunya adalah organ tubuh hati, Hati penting untuk mencerna makanan, menyingkirkan tubuh kita dari zat beracun dan menyimpan energi tubuh untuk digunakan bila diperlukan. Dalam indrustri kesehatan dan medis keakuratan prediksi sebuah penyakit sangatlah penting dan memerlukan keputusan yang efektif dalam mengambil suatu analisa dan keakuratan prediksi suatu penyakit yang diderita pasien (Rifai, 2013).

Dalam mendiagnosis ada atau tidak penyakit liver dapat digunakan acuan dari hasil tes fungsi hati yang dilaksanakan di laboratorium. Tes tersebut antara lain yaitu transaminase serum, fosfatase alkali, total bilirubin, bilirubin terkonjugasi, total protein, albumin, serta rasio albumin dan globulin. Dari hasil tes tersebut dapat dilihat hasil tes yang signifikan sebagai ciri adanya gangguan fungsi hati dengan menggunakan algoritma pohon klasifikasi karena dapat memperoleh informasi mengenai data klasifikasi pasien penyakit liver (Abdurrahman et al 2014).

Salah satu metode yang dapat digunakan Untuk memprediksi penyakit hipertensi adalah dengan menggunakan data mining. Data mining adalah serangkaian proses untuk menggali nilai tambah dari suatu kumpulan data berupa pengetahuan yang selama ini tidak diketahui secara manual (Muzakir et al, 2016).
Teknik dalam penelitian ini menggunakan dalam data mining adalah Algoritma decision tree (pohon keputusan). Dengan menggunakan teknik decision tree menggunanakan algoritma C4.5, akan menghasilkan pola, yaitu berupa rules yang dapat memprediksi penyakit liver. Pada studi ini juga akan menggunakan algoritma neural network dengan optimalis diharapkan hasil dari prediksi yang dilakukan bisa lebih akurat. Dan bisa digunakan untuk prediksi penyakit liver lebih baik

\section{TINJAUAN PUSTAKA}

Banyak metode Data Mining yang dipergunakan dengan berbagai tujuan dan hasil yang dicapai. Predictive analytics merupakan proses penggunaan data, algoritma statistic dan machine learning untuk mengidentifikasi kemungkinan hasil berdasarkan historical data. Dimana prediction adalah salah satu cabang dari discovery data mining [1].

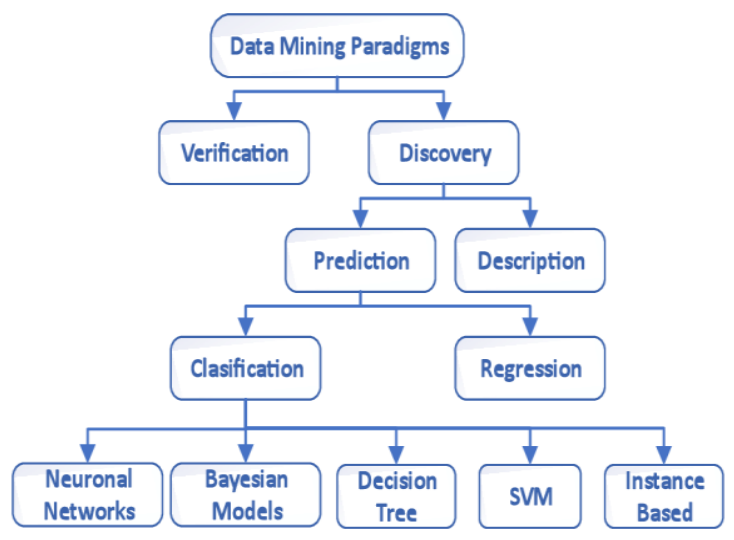

Gbr 1. Data Mining Taxonomy [1]

Pada Gambar 1 menunjukan data mining terdiri dari dua jenis yaitu data mining verification oriented berorientasi melakukan verifikasi data dan data 
mining discovery oriented digunakan untuk menemukan aturan baru atau pola mandiri dari sebuah set data. Metode prediction merupakan turunan dari data mining discovery oriented yang bertujuan membangun model perilaku untuk memperoleh sampel baru yang mampu memprediksi nilai-nilai dari satu atau lebih variabel yang terkait dengan sample. Selain itu prediksi dikembangkan untuk memperoleh pola yang membentuk pengetahuan dengan cara yang dapat dimengerti dan mudah dioperasikan. Data mining prediction terdiri dari teknik classification dan regression, algoritma yang dapat digunakan untuk teknik classification antara lain Neural Networks, Bayesian Models, Decision Tree, Support Vector Machine (SVM), dan Instance Based.

Classification adalah proses untuk menemukan model atau fungsi yang menjelaskan atau membedakan konsep/kelas data sehingga dapat memperkirakan kelas dari suatu objek yang labelnya tidak diketahui. Dimana model ini berupa aturan "jikamaka", berupa decision tree, formula matematis atau neural network. Proses classification dibagi menjadi 2 (dua) fase yaitu fase learning dan test, pada fase learning sebagian data yang telah diketahui kelas datanya dipergunakan untuk membentuk model perkiraan, yang selanjutnya masuk ke dalam fase test dimana model yang sudah terbentuk diuji dengan sebagian data lainnya untuk mengetahui akurasi dari model tersebut. Dan apabila akurasinya mencukupi, model ini dapat dipakai untuk prediksi kelas data yang belum diketahui.

Pada decision tree membagi kumpulan data yang besar menjadi himpunan-himpunan record yang lebih kecil dengan menerapkan serangkaian aturan keputusan. Setiap simpul daun pada decision tree menandai label kelas, dimana simpul yang bukan simpul akhir terdiri dari akar dan simpul internal yang terdiri dari kondisi tes atribut pada sebagian record yang mempunyai karakteristik yang berbeda. Simpul akar dan simpul internal ditandai dengan bentuk oval dan simpul daun ditandai dengan bentuk segi empat [2]. Berikut adalah struktur decision tree seperti yang ditunjukkan pada Gambar 2.

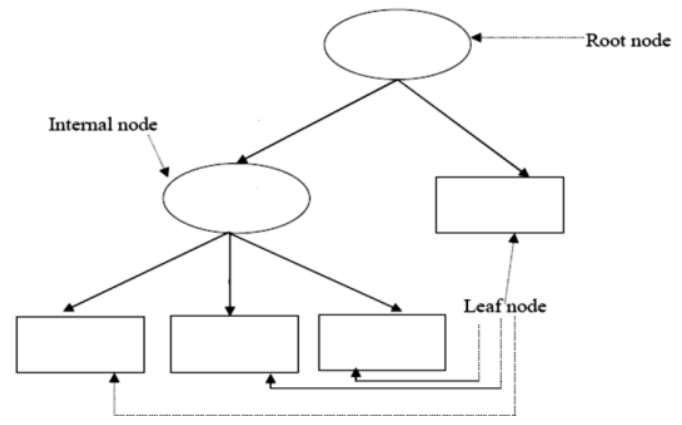

Gbr 2. Struktur Decision Tree

Ada beberapa konsep dalam decision tree, antara lain [2]:

1. Data dinyatakan dalam bentuk Tabel dengan atribut dan record.
2. Atribut menyatakan suatu parameter yang dibuat sebagai kriteria dalam pembentukan tree. Misalkan untuk menentukan main tenis, kriteria yang diperhatikan adalah cuaca, angin dan temperatur. Salah satu atribut merupakan atribut yang menyatakan data solusi per-item data yang disebut dengan target atribut.

3. Atribut memiliki nilai-nilai yang dinamakan dengan instance.

Dalam pengembangan data mining teknik classification dengan decision tree dalam algoritma C4.5 terdapat beberapa tahapan sebagai berikut [3] :

1. Mempersiapkan data training. Data training biasanya diambil dari data histori yang pernah terjadi sebelumnya atau disebut data masa lalu dan sudah dikelompokkan dalam kelas-kelas tertentu.

2. Menghitung akar dari pohon. Akar akan diambil dari atribut yang akan terpilih, dengan cara menghitung nilai gain dari masing-masing atribut, nilai gain yang paling tinggi yang akan menjadi akar pertama. Sebelum menghitung nilai gain dari atribut, hitung dahulu nilai entropy. Untuk menghitung nilai entropy digunakan rumus :

$$
\text { Entropy }(S)=\sum_{i=1}^{n}-p i \log _{2} p i
$$

Keterangan :

$\mathrm{S} \quad=$ Himpunan kasus

$\mathrm{n} \quad=$ jumlah partisi $\mathrm{S}$

$\mathrm{Pi}=$ proporsi $\mathrm{Si}$ terhadap $\mathrm{S}$

Kemudian hitung nilai gain menggunakan rumus

$$
\operatorname{Gain}(S, A)=\operatorname{entropy}(S)-\sum_{i=1}^{n} \frac{|S i|}{S} * \text { Entropy }(S i)
$$

Keterangan :
$\mathrm{S}=$ Himpunan Kasus
$\mathrm{A}=$ Fitur
$\mathrm{n}=$ Jumlah partisi atribut $\mathrm{A}$
$|\mathrm{Si}|=$ Proporsi Si terhadap $\mathrm{S}$
$|\mathrm{S}|$ = Jumlah kasus dalam $\mathrm{S}$

3. Ulangi langkah ke 2 dan langkah ke 3 hingga semua record terpatisi.

4. Proses partisi decision tree akan berhenti saat :
a. semua record dalam simpul $\mathrm{N}$ mendapat kelas yang sama.
b. Tidak ada atribut didalam record yang dipartisi lagi
c. Tidak ada record didalam cabang yang kosong

Neural networks atau artificial neural networks telah menjadi alat standar yang penting untuk data mining dan banyak digunakan untuk tugas-tugas data mining seperti pattern classification, time series analysis, prediction dan clustering. Dimana Neural networks atau artificial neural networks merupakan salah satu kelas dalam pemodelan kuantitatif yang pupuler dikalangan peneliti dan praktisi telah 
digunakan selama 20 tahun terakhir dan telah berhasil diterapkan untuk menyelesaikan berbagai variasi masalah di hampir semua bidang bisnis, industri dan sains [4].

Salah satu model neural network yang biasa Page | 57 dipergunakan yaitu model Hopfield Neural Network merupakan jenis neural networks yang mampu menyimpan memories atau pola tertentu dengan cara yang mirip dengan otak. Hopfield Neural Network dikembangkan oleh John Hopfield (Ahli Fisika, pemenang nobel 1982). Hopfield Neural Network mempunyai sifat assosiative memory, ini berarti seperti ingatan yang mampu menyimpan informasi yang pernah diberikan dan menampilkan kembali informasi tersebut apabila diminta. Hopfield Neural Network juga bersifat high-fault tolerance yaitu kemampuan untuk memilih salah satu pola yang paling mirip dalam ingatannya apabila pola yang diberikan tidak sama seperti salah satu pola dalam pembelajaran. Hopfield merupakan jaringan syaraf tiruan yang terhubung penuh (fully connected), yang berarti bahwa setiap unit terhubung dengan setiap unit lainnya. Jaringan ini memiliki bobot - bobot yang simetris. Pada Jaringan Hopfield, setiap unit tidak memiliki hubungan dengan dirinya sendiri. Secara matematik hal ini memenuhi $w i j=$ wji untuk $\mathrm{i} \neq \mathrm{j}$, dan wij $=0$ untuk $\mathrm{i}=\mathrm{j}$.

Jaringan Hopfield biner mempunyai suatu lapisan unit pengolah. Setiap unit pengolah mempunyai sebuah nilai aktivitas atau kondisi yang bersifat biner. Keseluruhan jaringan mempunyai kondisi pada setiap saat. Kondisi tersebut berupa vektor dari bilangan 0 dan 1. Setiap anggota vektor sesuai dengan unit pengolah dalam jaringan. Jadi pada setiap kondisi jaringan dapat digambarkan dengan vektor sebagai berikut: $\mathrm{U}=(\mathrm{U} 1, \mathrm{U} 2, \mathrm{U} 3, \ldots \ldots ., \mathrm{Un})=(++\ldots \ldots . . .+)$ Vektor ini mencerminkan sebuah jaringan yang terdiri dari $\mathrm{n}$ unit pengolah, dimana elemen ke i mempunyai kondisi ui . Dalam notasi ini, + menggambar sebuah unit pengolah dengan nilai 1 dan -1 menggambarkan sebuah unit pengolah dengan nilai 0 . [5]

Tiap hubungan mempunyai bobot. Bobot ini adalah suatu skalar yang berdasarkan pada kekuatan hubungan (Connection Strength). Kita misalkan Tji merupakan bobot dari unit i ke unit j. Dalam jaringan Hopfield bobot Tij dan Tji mempunyai nilai yang sama sehingga $\mathrm{Tji}=\mathrm{Tij}$. [6]

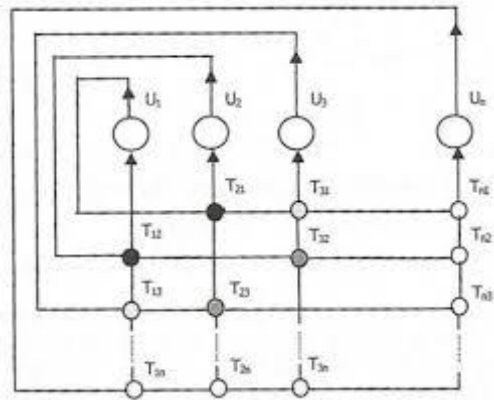

Gbr 3. Jaringan Hopfield dengan Lingkaran Menunjukan Nilai Bobot Tji [6]
Dalam jaringan Hopfield, yang dipandang sebagai sistem pengingat assosiatif, proses belajar adalah proses penambahan ingatan (memories) dari pola yang dilatihkan. Dalam sistem ini prosedur pembelajaran adalah prosedur pembentukan bobot koneksi Tij. Jika pada jaringan akan dilatihkan sejumlah $\mathrm{m}$ pola maka persamaan bobotnya adalah:

$$
T_{j i}= \begin{cases}\sum_{p=1}^{m} P_{j, p} P_{i, p} & \text { Jika } i \neq j \\ 0 & \text { Jika } i=j\end{cases}
$$

Dengan: $\mathrm{Tji}=$ Bobot koneksi dari neuron I dengan neuron $\mathrm{j} \mathrm{m}=$ Jumlah pola yang dilatihkan Pi,p = Elemen ke $\mathrm{i}$ dari vector pola $\mathrm{P}$ yang dilatihkan Pada awalnya matriks bobot bernilai $0(\mathrm{~T}=0)$. Pemberian nilai bobot (proses pembelajaran) dilakukan dengan menerapkan persamaan diatas untuk sejumlah pola yang dilatihkan sehingga terbentuk suatu matriks bobot. Selanjutnya jika ada pola yang akan dilatihkan lagi, persamaan tersebut diterapkan dengan kondisi bobot yang telah terbentuk sebelumnya sebagai kondisi awal. Dalam jaringan Hopfield ini terdapat batasan kapasitas penyimpanan ingatan dari pola yang dilatihkan. Untuk jaringan dengan neuron sejumlah $\mathrm{N}$, agar sistem stabil, batasan kapasitas pola yang diingat adalah $2 \mathrm{~N}$. Awalnya pada jaringan ditetapkan kondisi untuk tiap unit pengolah. Prosedur pembaharuan diterapkan pada unit - unit dalam jaringan Hopfield. Pada satu saat, satu unit diperbaharui. Prosedur pembaharuan mempengaruhi kondisi tiap unit, kadang mengubah kondisinya dan kadang dibiarkan pada kondisi yang sama. Pembaharuan dari unit - unit pengolah berlanjut sampai tidak terjadi lagi perubahan. Ketika penjumlahan ini selesai dihitung, unit pengolah akan mengevaluasi apakah hasil penjumlahan lebih besar atau lebih kecil dari 0. Jika hasil penjumlahan lebih besar atau sama dengan 0 , maka keluaran unit di set 1. Jika hasil penjumlahan lebih kecil dari 0 , keluaran unit akan di set 0 .

Tiap kondisi dari jaringan mempunyai sekumpulan energi. Nilai ini didefinisikan dengan:

$$
E=-\frac{1}{2} \sum_{j} \sum_{\substack{i \\ i \neq j}} T_{j i} U_{j} U_{i}
$$

Dengan:

Tji $=$ Bobot koneksi dari neuron $\mathrm{i}$ dengan neuron $\mathrm{j}$

$\mathrm{Uj}=$ Unit pengolah pada neuron $\mathrm{ke} \mathrm{j}$

Persamaan ini dihubungkan dengan "energi" meskipun ini tidak menggambarkan energi yang nyata seperti pada sistem fisika. Fungsi energi dari persamaan diatas adalah sebuah fungsi objektif yang diminimalkan oleh jaringan. Pembaharuan dari jaringan Hopfield merupakan prosedur konvergen dimana energi dari keseluruhan jaringan akan menjadi semakin kecil. Pada akhirnya jaringan akan berada 
pada posisi stabil dimana pada kondisi ini energi berada pada nilai minimum [6].

\section{PEMBAHASAN}

Pembuatan model C4.5 dilakukan pada dataset

Page 58 yang terdiri dari 11 atribut yang merupakan atribut dari diagnosis penyakit liver dan class yang merupakan hasil akhir prediksi. Data kemudian di validasi agar proses pelatihan dapat berjalan dengan cepat dan mampu digunakan untuk melakukan pelatihan.

Model dari algoritma C4.5 yaitu berupa pohon keputusan, untuk dapat membuat pohon keputusan, langkah pertama adalah menghitung jumlah class yang terkena penyakit liver yang positif liver dan yang negatif liver dari masing-masing class berdasarkan atribut yang telah ditentukan dengan menggunakan data training. Kemudian menghitung Entropy (Total) menggunakan persamaan (2.1)

Data tranning yang digunakan untuk model Neural Network sama, namun nilai atribut merupakan data yang sudah dikonversi kedalam nilai numerik. Gambar 4.6 adalah neural net yang dihasilkan dari pengolahan data training dengan metode neural network adalah multilayer perceptron. Terdiri dari tiga layer, yaitu Input layer terdiri dari sepuluh neuron (sembilan neuron terdiri dari atribut dan satu neuron adalah bias), satu buah hidden layer yang terdiri dari delapan buah neuron, dan dua buah output layer yang merupakan hasil prediksi Positif Liver dan Negatif Liver, berikut model Neural Network dengan Framework Rapidminer versi 5.2.001. Sehingga jika model tersebut dijalankan maka akan didapatkan hasil seperti gambar 4 dibawah ini.

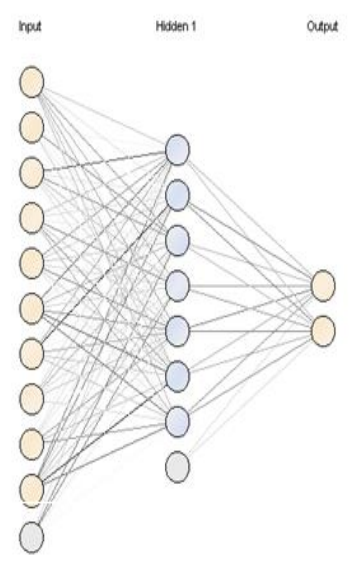

Gambar 4. Neural net yang dihasilkan dengan metode Neura Network

Untuk setiap data pada data training, dihitung input untuk neuron berdasarkan nilai input dan jaringan. Bobot awal untuk input layer, hidden layer, dan bias diinisialisasi secara acak biasanya berkisar 0,1 s/d 1,0 (kusrini,2009.p,201). Nueron bias terdiri dari dua, yaitu pada input layer yang terhubung dengan neuron-neuron pada hidden layer, dan pada hidden layer yang terhubung pada output layer. Setelah semua nilai awal diinisialisasi, kemudian dihitung input dari tiap neuron untuk membangkitkan output dengan menggunakan fungsi aktifasi sigmoid. Setelah didapat nilai dari fungsi aktifasi, hitung nilai error antara nilai yang diprediksi dengan nilai yang sesungguhnya. Setelah nilai error dihitung, selanjutnya dibalik ke layer sebelumnya (backpropagated).

\section{Komparasi Model Decision Tree dengan Algoritma Neural Network}

Hasil pengujian menyimpulkan bahwa Atribut yang mempengaruhi pengujian adalah 11 atribut. Hasil pengujian model decision tree dan algoritma Neural Network dapat dilihat pada tabel berikut:

TABEL I

PENGUJIAN ALGORITMA KLASIFIKASI DECISION TREE DAN NEURAL NETWORK

\begin{tabular}{|l|c|c|}
\hline & Accuracy & AUC \\
\hline C4.5 & $75.56 \%$ & 0.898 \\
\hline $\begin{array}{l}\text { Neural } \\
\text { Network }\end{array}$ & $74,17 \%$ & 0,671 \\
\hline
\end{tabular}

Dari hasil pengujian diatas, dengan dilakukan evaluasi baik secara confusion matrix maupun ROC curve terbukti bahwa pengujian yang dilakukan algoritma C4.5 memiliki nilai akurasi yang lebih tinggi dibanding menggunakan algoritma Neural Network. Nilai akurasi untuk model algoritma C4.5 sebesar $75,56 \%$ dengan nilai AUC 0,898 dan nilai akurasi algoritma Neural Network sebesar 74,17\% dengan AUC 0,671. Berdasarkan nilai tersebut diperoleh selisih akurasi sebesar 1,39\% dan selisih AUC sebesar $0,227 \%$.

\section{KESIMPULAN}

Algoritma Decision Tree dan Neural Network dapat diimplementasikan untuk membuat sebuah system dalam memprediksi penyakit liver. Algoritma Decision Tree memiliki nilai true positive lebih besar dibandingkan Neural Network, ini artinya tingkat memprediksi untuk penyakit liver lebih akurat dengan menggunakan Decision Tree dari pada Neural Network.

\section{REFERENSI}

[1] Maimon, O., \& Rokach, L. (2010). Data Mining and Knowledge Discovery Handbook Second Edition. London: Springer.

[2] Muzakir, A., \& Wulandari R.A., (2016). Model Data Mining sebagai Prediksi Penyakit Hipertensi Kehamilan dengan Teknik Decision Tree. Scientific Journal of Informatics; Vol. 3, No. 1

[3] Larose, D. T. (2005). Discovering Knowledge in Data An Introduction to Data Mining. New Jersey: John Willey and Sons.

[4] Widrow B., Rumelhart D.E., Lehr M.A., (1994), Neural networks: applications in industry, business and science, Communications of the ACM; 37:93-105 
[5] Azmi, Z., \& Freizello, H., (2017), Implementasi Hopfield untuk Pengenalan Karakter Hiragana. Journal of Information System, Informatics and Computing; Vol.1, No. 1

[6] Hermawan, A. (2006), Jaringan Saraf Tiruan Teori dan Aplikasi. Yogyakarta: Penerbit Andi.

Page | 59 